Wuri Arenggoasih, Pengaruh Brand Communication, Service Quality dan Brand Personality ...

\title{
PENGARUH BRAND COMMUNICATION, SERVICE QUALITY DAN BRAND PERSONALITY ANGGOTA DEWAN TERPILIH MELALUI BRAND TRUST \\ TERHADAP BRAND LOYALTY PEMILIH (Studi Partai Politik Gerindra)
}

\author{
Wuri Arenggoasih \\ Mahasiswa Program Studi Magister Ilmu Komunikasi FISIP UNDIP Angkatan VII \\ Email : mama.wuri25@gmail.com
}

\begin{abstract}
Talking about marketing communications today is not only to products but has penetrated into the political field. Indonesia as a democratic state which is to become the member of parliament needs to have as many voters and a strong loyalty to the sustainability of the council itself and the political parties.Brand Communication, Service Quality and Brand Personality emerged as a voter votes for member of parliament which gives the possibility of influence in building Brand Loyalty (loyalty) through Brand Trust (trust). The theory used is the Strategy Choice Theory suggests one of the forms Compliance Gaining which argued about strategies of verbal / non verbal and emphasized specific results loyalty. This research has shown that Brand Communication, Service Quality and Brand Personality as a real form of strategies verbal / nonverbal become voter votes for member of parliament which influence the Brand Loyalty through Brand Trust as a mediating variable.
\end{abstract}

Keyword : marketing communications, Brand Communication, Service Quality, Brand Personality, Brand Loyalty, Brand Trust

\section{A. PENDAhULUAN}

Pada Pemilu 2019 mendatang, Indonesia akan melaksanakan Pemilu serentak. Artinya, pemilu legislatif dan pemilu presiden akan diselenggarakan serentak. Hal ini didasarkan pada keputusan Mahkamah Konstitusi (MK) pada tanggal 23 Januari 2014 atas gugatan yang diajukan oleh Effendi Gazali (Aliansi Masyarakat Sipil). Menurut Gazali, terdapat sejumlah pasal di Undang-Undang Pemilihan Presiden yaitu Pasal 3 ayat 5, pasal 12 ayat 1 dan 2, pasal 14 ayat 2, dan pasal 112 UU No 42 Tahun 2008 dikarnakan bertentangan dengan UUD 1945 dan tidak memiliki kekuatan hukum mengikat (BBC Indonesia, 2014 dan Ana, dkk, 2014).
Pada Pemilu 2014, diperoleh jumlah suara sah seluruh partai politik sebesar 124.972.491 kartu suara dan prosentase ambang batas sebesar 3,50\% (lampiran keputusan KPU No: 412/Kpts/KPU/TAHUN 2014 tanggal 9 Mei 2014). Pada lampiran tersebut, ditunjukkan bahwa PDI Perjuangan memperoleh suara paling tinggi dengan 23.681.471 suara atau 18,95 persen kemudian peringkat kedua adalah Partai Golkar yang memperoleh suara 18.432.312 suara atau 14,75 persen dan peringkat ketiga Partai Gerindra memperoleh 14.760.371 suara atau 11,81 persen.

Target yang harus tercapai adalah catatan penting sebagai permasalahan yang harus dilakukan perbaikan bagaimana Partai 
Gerindra lebih bisa mengoptimalkan faktorfaktor yang dapat mempengaruhi perilaku pemilih. Tercatat pada sejarah Indonesia dimana Pilpres 2014 menjadi persaingan sengit antara Jokowi sebagai calon presiden dari anggota partai PDI Perjuangan dan Prabowo Subianto sebagai calon presiden dari anggota partai Gerindra. Di tahun itu, suhu politik antara PDI Perjuangan dan Gerindra sangat panas, bahkan hingga saat ini Partai Gerindra "melabeli" sebagai partai oposisi untuk pemerintahan Jokowi (PDI P).

Olehkarena itu, bila ingin bertahan Partai Gerindra harus memiliki mengembangkan hubungan relasional dengan masyarakat adalah menciptakan loyalitas konstituen terhadap partai politik atau kandidat individu, karena masing-masing kandidat berharap bahwa partai politik mereka dapat memenangkan pemilu di masa-masa mendatang. Hal ini tidak akan dicapai tanpa loyalitas pemilih. Konstituen yang loyal akan mengurangi ketidakpastian yang berkecamuk di tengah-tengah para pemilih dalam memilih partai politik tertentu. Mencapai loyalitas dibutuhkan konsistensi dan bukti nyata dan janji serta harapan yang diberikan melalui anggota dewan yang terpilih.Loyalitas merek (brand loyalty) sebagai suatu ukuran keterkaitan pelanggan kepada sebuah merek. Seorang pelanggan yang sangat loyal kepada suatu merek tidak akan dengan mudah memindahkan pembeliannya ke merek lain, apa pun yang terjadi dengan merek tersebut (Aaker, 1997:56).

Pada Penelitian ini merupakan penelitian kuantitatif dengan paradigm positivism karena penelitian ini ingin mengetahui pengaruh dari efek variablevariabel (brand communication, service quality dan brand personality) yang dilakukan anggota dewan terpilih melalui brand trust dalam brand loyalty pada pemilih tetap partai politik (terutama pada Partai Gerindra). Masuk pada tradisi sosiopsikologis dimana teori-teori pesan ini memandang pilihan individu dan strategi untuk meraih tujuan dari sebuah pesan (Littlejohn \& Foss, 2011: 174, terjemahan). Secara teori pada Strategy Choice Theory, upaya untuk mendapatkan kepatuhan dari orang lain ada di mana-mana. Compliance gaining dalam komunikasi adalah bentuk persuasi yang pada gilirannya, adalah bentuk pengaruh. Pengaruh bila dipahami sebagai istilah umum yang meliputi komunikasi baik disengaja dan tidak disengaja untuk mengubah orang lain keyakinan, sikap, niat, atau perilaku. Compliaince gaining dan kepatuhan biasanya menolak dipandang sebagai bagian dari persuasi yang melibatkan upaya yang disengaja untuk mengubah lain perilaku itu. Seperti namanya, Complain gaininng menekankan hasil spesifik: kepatuhan. Penekanannya tidak pada perubahan sikap, tetapi lebih pada behavioural conformity. Penelitian tentang kepatuhan terdiri dari berbagai strategi verbal dan nonverbal untuk meningkatkan kemungkinan mengamankan kepatuhan orang lain. Janji pahala dan ancaman hukuman adalah dua dari banyak strategi seperti itu. Lintasan penelitian di bidang ini telah menekankan arena antarpribadi, atau satu-satu kepatuhan memperoleh, meskipun konteks lain telah dipelajari juga (Littlejohn \& Foss, 2009: 155).

Pada ilmu politik terdapat beberapa pendekatan seperti pendekatan pilihan rasional, public choice dan collective choice.Model pilihan publik didasarkan pada individualisme metodologis, gagasan bahwa seorang individu adalah unit yang tepat dari analisis.Hanya individu yang membuat pilihan; bermasyarakat, mengikuti pemerintah, atau bahkan menjadi kelompokkelompok kecil yang tidak melakukannya. Menururt James Buchanan, public choice 
dipahami sebagai politik maka membuka tentang pertanyaan tentang bagaimana insentif yang dihadapi oleh individu diterjemahkan ke dalam tindakan kolektif (Reksulak, Razzolini, Shughart, 2013: 4).

Komunikasi selalu mempunyai efek atau pengaruh atas satu atau lebih orang yang terlibat dalam tindak komunikasi.Kemunculan konsep komunikasi pemasaran memberi kesadaran perlunya konsistensi pesan kampanye pemasaran, serta keterkaitan media komunikasi yang digunakan agar menghasilkan konsistensi reputasi antara citra merek dengan citra korporat (Hermawan, 2012: 51).Komunikasi pemasaran adalah istilah yang menggambarkan bagaimana organisasi perusahaan atau pemerintahan mengkomunikasikan pesan-pesan kepada khalayak sasaran yaitu kelompok konsumen potensial yang menerima pesan-pesan pemasaran mereka (Lwin, Aitchison, 2002: 5). Keberhasilan dalam menerapkan konsepkonsep marketing terutama di dunia politik, yang memungkinkan perusahaan unggul dalam persaingan memenuhi kebutuhan(need), keinginan (want) dan harapan (expection) konsumen (Nursal, 2004: 4). Menurut Philip Kotler dan Neil Kotler (Newman,1999: 3):

political marketing, the making of successful candidates and causes, is a major growth industry affecting virtually every citizen and institution. Candidates, to be successful, have to understand their markets, the voters and their basic needs and aspiration and the constitueneies they respresent or seek to represent.

Menurut Terrace (2002 : 4) Komunikasi pemasaran (marketing communication) adalah aspek yang penting dalam keseluruhan misi pemasaran serta penentu suksesnya pemasaran (marketing). Marketing communication (Marcom) adalah istilah yang menggambarkan bagaimana organisasi, perusahaan atau pemerintahan mengkomunikasikan pesan-pesan kepada khalayak mereka (Lwin \& Aitchison, 2005: 5).

Disinilah konsep komunikasi pemasaran yang dipadukan pemasaran politik diperlukan untuk menjawab kebutuhan kandidat kepala daerah semasa kampanye.konsep pemasaran politik, sebagaimana pemasaran produk barang dan atau jasa pada umumnya memiliki kekhususan produknya yang ditawarkan pada "pasar politik". Komunikasi pemasaran memiliki 4 elemen yang saling terkait yaitu : product, price, place, dan promotion (Terrace, 2004: 4). Sedangkan marketing politik (Political marketing) menggunakan konsep marketing secara luas, tidak hanya terbatas pada teknik marketing bahkan hingga strategi marketing dari teknik publikasi, menawarkan ide dan program dan desain produk sampai ke market serta pemrosesan informasi. Political marketing memiliki 9 elemen yaitu positioning, policy, person, party, presentation, push marketing, pull marketing, pass marketing dan polling (Nursal, 2004: 295-296). Sehingga dapat disimpulkan konsep political marketing communication merupakan penggabungan dari $4 \mathrm{P}+9 \mathrm{P}$ yang mana ditujukan kepada political market yang terdiri dari media massa, pemilih dan influencers.

Komunikator pemasaran dalam berbagai kapasitas mereka (baik sebagai pengiklan, wiraniaga, pelaku public relations, dan lain-lain), mengembangkan dan menyampaikan pesan dan obyek yang berbeda: produk, jasa, toko, kegiatan bahkan orang. Walaupun istilah-istilah tersebut menjelaskan bentuk objek pemasaran yang berbeda, narnun ada satu istilah yang dapat dipakai sebagai ringkasan dan seluruh bentuk 
objek pemasaran itu, yaitu "merek" (Shimp, 2002: 7). Citra merek yang kuat memungkinkan pabrikan meraih kepercayaan dan pada perspektif konsumen, merek yang terpercaya merupakan jaminan atas konsistensi kinerja suatu produk dan menyediakan manfaat apa pun (dalam bentuk status atau gengsi) yang dicari konsumen ketika membeli produk atau merek tertentu.

Menurut Schultz dan Barnes (1999), Brand communication masuk ke dalam brand strategy yang berarti manajemen merek dapat diartikan sebagai kegiatan yang mengatur semua elemen-elemen yang bertujuan untuk membentuk suatu brand.The brand communication strategy is to set the focus on the general purpose of the respective communication efforts (Kotler dan Pfoertsch, 2006: 109). Tujuan dari brand communication telah mengekspos penonton untuk merek, dimana efeknya dapat dimaksimalkan dalam hal kesadaran meningkat dan recall yang lebih tinggi, sehingga pelanggan akan membeli merek yang memiliki recall tertinggi; dan untuk memuaskan pelanggan ke tingkat optimal.

Menurut Low dan Lamb (2000), Brand communication didefinisikan sebagai "evaluasi keseluruhan konsumen dari merek apakah baik atau buruk", sikap merek merangkum arti bahwa konsumen melampirkan merek, yang pada gilirannya efek perilaku pembelian mereka (Terrill, 1992, p. 25 dalam Zehir, Sahin, Kitapci dan Osahin. 2011: 1219). Sikap merek positif seperti kepercayaan merek dan loyalitas sangat penting untuk keberhasilan jangka panjang dan keberlanjutan merek (Hoek et al, 2000).

Brand communication terdiri dari packing, advertising, surround (event), dan direct marketing (Paraneswara, 2006: 138). Menurut Josh McQueen iklan bekerja dalam banyak cara, tetapi salah satu yang paling umum dan kuat namun dengan gaya yang sederhana, wawasan pada iklan memperkuat kebenaran tentang merek yang memperdalam kepercayaan antara konsumen dan merek.Menurut Li \& Miniard. 2006, p. 103, "Advertising has been shown to be able to enhance a product's perceived trustworthiness both in the absence of past experience (new products) and with brands with previous usage (lapsed brands) (McQueen, 2012: 22).

Dari pemaparan di atas dapat disimpulkan bahwa brand communication adalah kemampuan komunikasi suatu merek yang memberikan hasil yang positif kepada pemilih sehingga akan menimbulkan kepercayaan terhadap suatu merek (brand trust). Melalui penelitian ini akan megukur besaran efek brand communication yang dilakukan anggota dewan terpilih terhadap tingakat kepercayaan merek (brand trust) para pemilih tetap pada Partai Gerindra.

Kualitas layanan (service quality) sangat bergantung pada tiga hal, yairu system teknologi, dan manusia.Faktor manusia memegang kontribusi terbesar sehingga kualitas layanan relatif lebih sulit (ditiru dibandingkan kualitas produk dan barga. Salah satu konsep kualitas layanan yang popular adalah SerQual (Durianto,dkk, 2004: 40). Berdasar konsep ini, kualitas layanan diyakini memiliki lima dimensi, yaitu reliability (keandalandalam memberikan pelayanan), responsiveness(kecepatan pelayanan), assurance(menanamkan rasa percaya dan keyakinan), empathiy (kemudahan dalam menjalin hubungan) dan tangible/ bukti fisik (Durianto,dkk, 2004: 4041).

A high level of responsiveness, representing and expressing as a trust cue, can convey the trustworthiness to the 
customers (Corritore et al., 2003 dalam Yan, 2014: 175). Tingkat responsif yang tinggi, mewakili dan mengungkapkan sebagai isyarat kepercayaan, dapat menyampaikan kepercayaan kepada pelanggan.Kualitas layanan diwujudkan melalui pemenuhan kebutuhan dan keinginan pelanggan serta ketepatan penyampaiannya dalam mengimbangi atau melampaui harapan pelanggan (Tjiptono dan Chandra, 2012: 77).

Dari pemaparan di atas dapat disimpulkan bahwa service quality adalah kualitas pelayanan didefinisikan sebagai penilaian global atau sikap sehubungan dengan the overall excellence atau superiority of the service (Parasuraman et al, 1988 dalam Zehir,Sahin, Kitapci dan Osahin. 2011: 1220) pada suatu merek (service quality) yang memberikan hasil yang positif kepada konsumen sehingga akan menimbulkan kepercayaan terhadap suatu merek (brand trust). Melalui penelitian ini akan megukur besaran efek service quality yang dilakukan anggota dewan terpilih terhadap tingakat kepercayaan merek (brand trust) para pemilih tetap terutama pada Partai Gerindra.

Brand personality (kepribadian merek) merupakan tahap perkembangan merek, yang berarti merek yang mencerminkan kepribadian (Rangkuti, 2004). Pemanfaatan personalitas merek sebagai upaya dalam membedakan merek terhadap pesaingnya akan lebih efektif pada merek yang secara fungsi atau fisik sangat sulit dibedakan antara satu dan lainnya. Menurut Bauer Mader, Keller (2001) sebuah personlitas merek dapat membantu proses komunikasi pada konsumen dikarenakan memberi kemudahan konsumen dalam mengidentifikasi merek. Langkah pertama yang perlu diperhatikan dalam membangun personalitas adalah memilih macam karakter personalitas yang akan digunakan. Mungkin ada lebih dari 200 karakter yang dimiliki oleh seseorang tetapi hanya beberapa yang disukai salahsatunya kepercayaan/trustworthiness (Soehadi, 2005: 51).Brand personality adalah mendefinisikan sebagai seperangkat karakteristik manusia yang terkait dengan merek (Aaker 1997). Ada 5 dimensi dari personalitas merekdalam penelitian yang dilakukan Aaker (1997), yaitu :Sincerity (ketulusan), Excitement (sesuatu yang menyenangkan), Competence (kompetensi), Sophistication(secara duniawi/kelas sosial) dan Ruggedness (ketegasan).

Dari pemaparan di atas dapat disimpulkan bahwa brand personality adalah meningkatkan preferensi konsumen pada suatu merek yang memberikan hasil yang positif kepada konsumen sehingga akan menimbulkan kepercayaan terhadap suatu merek (brand trust). Melalui penelitian ini akan megukur besaran efek brand personality anggota dewan terpilih terhadap tingkat kepercayaan merek (brand trust) para pemilih tetap terutama pada Partai Gerindra.

Brand trust (kepercayaan merek) merupakan faktor mediator penting pada perilaku pelanggan sebelum dan setelah pembelian produk; dan hal itu menyebabkan loyalitas jangka panjang dan memperkuat hubungan antara dua pihak (Liu et al, 2011 dalam Geçti \& Zengin, Vol. 5, No. 2, 2013: 112). Kepercayaan merek dapat didefinisikan sebagai kesediaan konsumen rata-rata mengandalkan kemampuan merek untuk menjalankan fungsinya dinyatakan (Chaudhuri \& Holbrook, 2001: 82 dalam Geçti \& Zengin, Vol. 5, No. 2, 2013: 112). Menurut Luarn dan Lin (2003) kepercayaan adalah sejumlah keyakinan spesifik terhadap integritas (kejujuran pihak yang di percaya dan kemampuan menepati janji), benevolence (perhatian dan motivasi yang dipercaya untuk bertindak sesuai dengan kepentingan yang 
mempercayai mereka), competency kemampuan pihak yang dipercaya untuk melaksanakan kebutuhan yang mempercayai) dan predictability konsistensi perilaku pihak yang dipercaya (Ferrinadewi, 2008: 147).

Kepercayaan memainkan peran kunci dalam meningkatkan loyalitas merek dan juga memiliki dampak pada faktor-faktor seperti mempertahankan pangsa pasar dan fleksibilitas harga yang terkait dengan hasil pemasaran (Gommans et al., 2001 dalam Geçti \& Zengin, Vol. 5, No. 2, 2013: 112). Untuk memenangkan kembali loyalitas dan untuk meniru keberhasilan pemasar industri.pemasar konsumen mulai merangkul gagasan untuk membangun hubungan dengan pelanggan dan memenangkan kepercayaan mereka (Bennel, 1996 dalam Lau, Lee, 1999: 344).

Dari pemaparan di atas dapat disimpulkan bahwa kepercayaan merek (brand trust) adalah kesediaan konsumen untuk mempercayai suatu merek dengan segala resikonya karena adanya harapan di benak mereka bahwa merek tersebut akan memberikan hasil yang positif kepada konsumen sehingga akan menimbulkan kesetiaan terhadap suatu merek (brand loyalty). Melalui penelitian ini akan megukur besaran efek brand communication, service quality dan brand personality yang dilakukan anggota dewan terpilih terhadap tingakat kepercayaan merek (brand trust) para pemilih tetap terutama pada Partai Gerindra.

Setiap perusahaan (calon/anggota dewan) menginginan untuk memiliki merek dengan loyalitas pemilih yang tinggi.Pada puncak persaingan, bagi perusahaan, bicara merek adalah bicara loyalitas (brand loyalty). Karena pesaing sangat banyak dan mempunyai taktik pemasaran yang hehat, ditambah konsumen juga makin pandai memilih (Simamora, 2003: 4), bahkan loyalitas adalah salah satu cara dengan mana konsumen mengungkapkan / nya kepuasan nya dengan kinerja produk atau jasa yang diterima (Bloemer dan Kasper, 1995; Ballester dan Aleman, 2001 dalam Zehir,Sahin, Kitapci dan Osahin, 2011: 1221). Menurut Aaker (1996) mendefinisikan loyalitas merek merupakan suatu ukuran keterkaitan pelanggan terhadap sebuah merek. Ukuran ini mampu memberikan gambaran tentang kemungkinan seorang pelanggan beralih ke produk lain terutama pada suatu merek tersebut didapatinya adanya perubahan, baik menyangkut harga atau atribut lain (Aaker, 1996: 21). Merek tanpa basis pelanggan setia biasanya rentan atau memiliki nilai hanya potensi untuk menciptakan pelanggan setia (Aaker, 1996: 21-22).

Dari pemaparan di atas dapat disimpulkan bahwa brand loyalty adalah tujuan utama dari para anggota dewan yang terpilih Partai Gerindra untuk menjaga para pemilih tetap partai untuk tetap setia terhadap partai. Melaui penelitian ini akan megukur besaran efek brand communication, service quality dan brand personality yang dilakukan anggota dewan terpilih Partai Gerindra terhadap tingakat kepercayaan merek (brand trust) para pemilih tetap yang berpengaruh pula terhadap brand loyalty.

Berikut bagan antara variable : 
Bagan 1.5 : Bagan Antara Variable Brand Communication, Service Quality Dan Brand Personality Anggota Dewan Terpilih Melalui Brand Trust Dalam Brand Loyalty Partai Politik (Penelitian Empiris Pada Partai Gerindra)

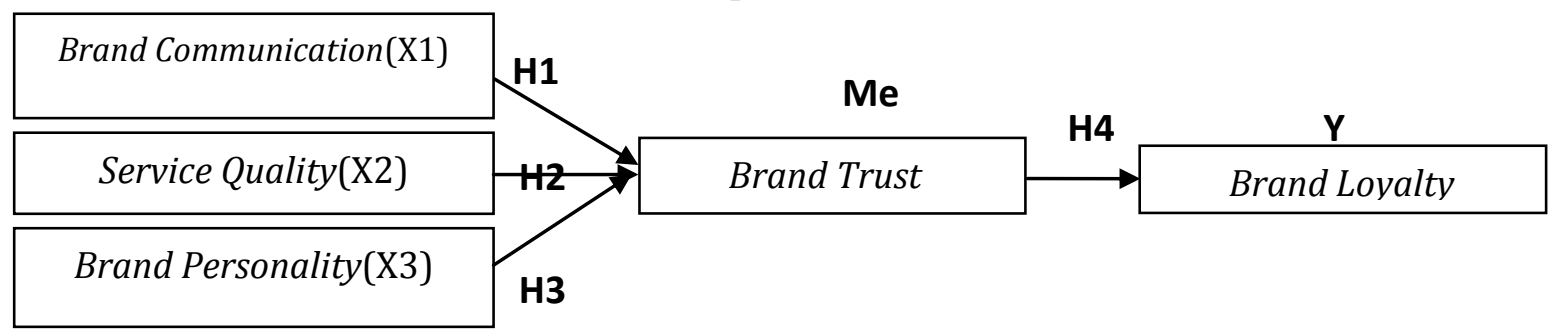

\section{B. METODE PENELITIAN}

Tipe penelitian yang digunakan adalah tipe eksplanatif yaitu menghubungkan atau mencari sebab akibat dua atau lebih konsep (variabel) yang akan diteliti. Periset membutuhkan definisi konsep, kerangka konseptual dan kerangka teori.Periset perlu melakukan kegiatan berteori untuk menghasilkan dugaan awal (hipotesis) antara variabel satu dengan yang lainnya (Kriyantono, 2010:69).Menurut data yang diperoleh dari KPU Kabupaten Semarang, diperoleh jumlah pemilihsebanyak 720.499 pemilih (populasi).Setelah dihitung dengan rumus solvin didapatkan jumlah sampel sebanyak 400 responden. Guna mempermudah penjangkauan pemilih pemula, peneliti menggunakan Teknik sampling probabilitas dengan Area Probability Sampling yang dibagi menjadi 5 tahap area (Eriyanto, 2007:157-160).

Berikut penggambarannya :

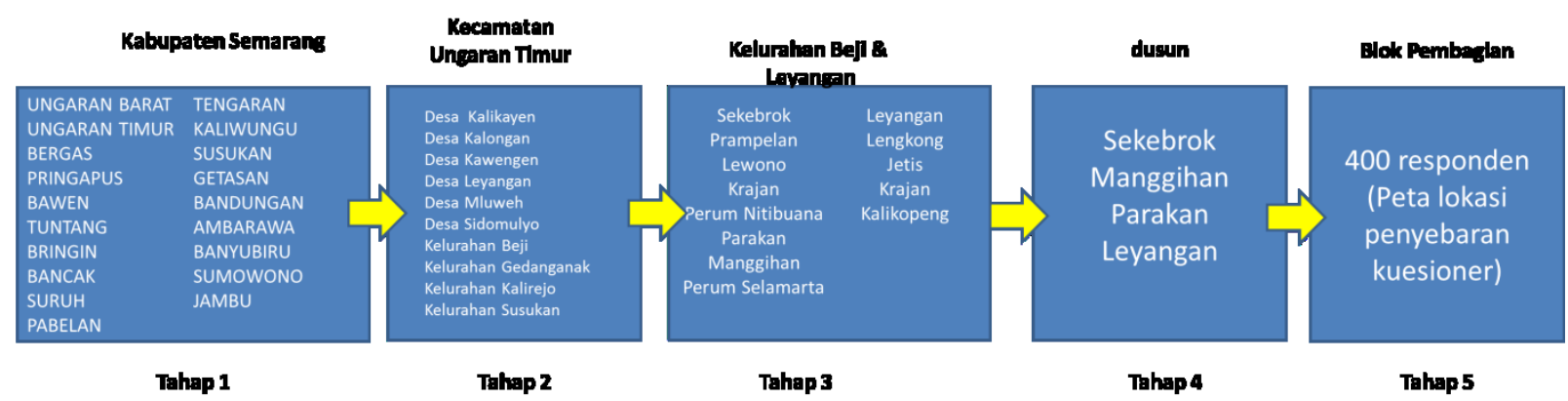

Data yang diperoleh adalah data melakukan proses regresi linier dan regresi nominal yang selanjutnya data tersebut dianalisis menggunakan regresi. Teknik berganda kemudian melakukan analisis variable mediasi (brand trust). analisis data yang digunakan adalah

\section{HASIL PENELITIAN}

Tabel 1: Hasil Analisis Regresi Brand Communication, Service Quality Dan Brand Personality Anggota Dewan Terpilih Terhadap Brand Trust

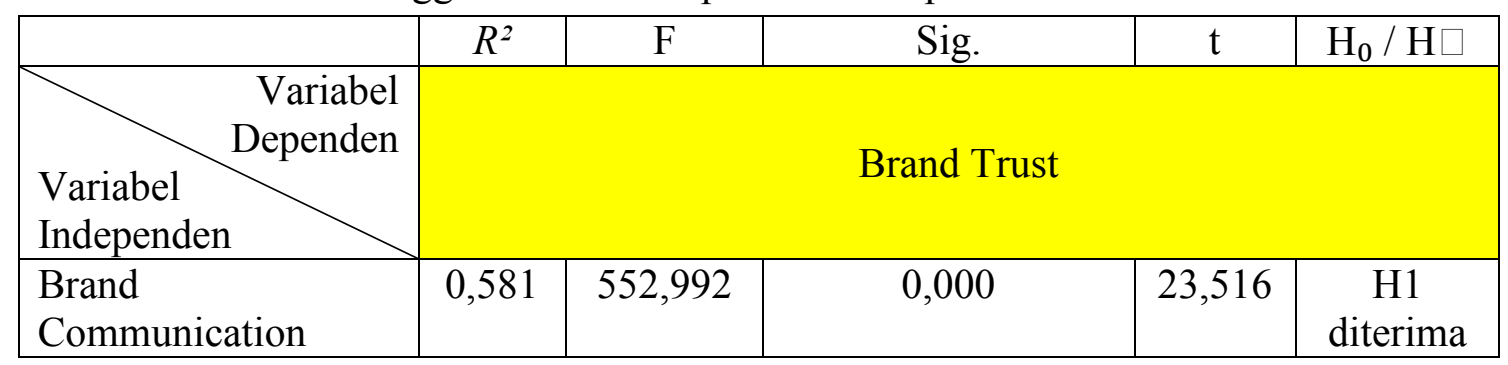




\begin{tabular}{|l|c|c|c|c|c|}
\hline Service Quality & 0,633 & 685,940 & 0,000 & 26,190 & $\begin{array}{c}\mathrm{H} 2 \\
\text { diterima }\end{array}$ \\
\hline Brand Personality & 0,679 & 840,887 & 0,000 & 28,998 & $\begin{array}{c}\mathrm{H} 3 \\
\text { diterima }\end{array}$ \\
\hline Brand Trust & 0,422 & 290,450 & 0,000 & 17,043 & $\begin{array}{c}\mathrm{H} 4 \\
\text { diterima }\end{array}$ \\
\hline $\begin{array}{l}\text { Brand } \\
\begin{array}{l}\text { Communication, } \\
\text { Service Quality dan } \\
\text { Brand Personality }\end{array}\end{array}$ & 0,713 & 327,854 & $\begin{array}{c}0,000 \\
\text { Brand Loyalty } \\
\text { mersama-sama } \\
\text { Brand Trust) }\end{array}$ & $\begin{array}{c}\mathrm{H}_{0} \\
\text { ditolak }\end{array}$ \\
\hline
\end{tabular}

Sumber : Olahan data primer atau kuesioner

Pada bagian ini analisis Brand terhadap Brand Loyalty dilakukan pengolahan Communication, Service Quality dan Brand data dengan SPSS melalui langkah-langkah Personality Anggota Dewan Terpilih melalui sebagai berikut (Ngatno, 2015: 146-159): Brand Trust (sebagai variable mediasi)

a. Membuat diagram jalur berdasarkan model konseptual kedalam model analisis

Bagan 2 : Bagan Diagram Jalur Antara Variable Brand Communication, Service Quality dan Brand melalui Brand Trust Dalam Brand Loyalty

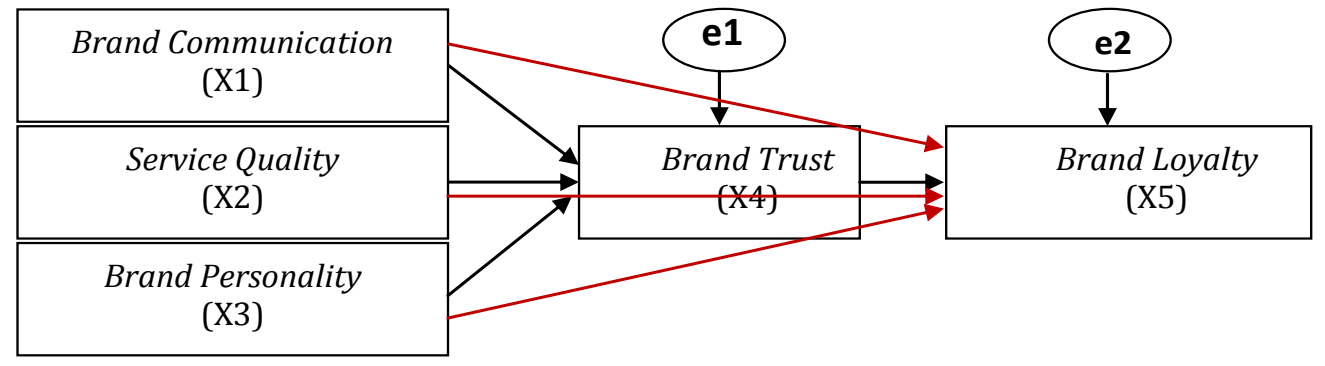

b. Melakukan analisis factor terhadap

c. Melakukan analisis regresi linier masing-masing variable, kemudian dapatkan hasil dari score $\rightarrow$ save as sederhana antara variabel dan regresi linier berganda, dengan hasil sbb: variabel

Table 2: Ringkasan Hasil regresi sederhana antara variable Brand Communication, Service Quality, Brand Personality Brand Trust dan Brand Loyalty

\begin{tabular}{|c|l|c|c|c|}
\hline Variabel & \multicolumn{1}{|c|}{ Keterangan } & $\begin{array}{l}\text { Besarnya } \\
\text { koefisien }\end{array}$ & $\mathrm{t}$ & Sig. \\
\hline $\mathrm{X}_{1}-\mathrm{Me}$ & $\begin{array}{l}\text { Pengaruh variabel independen (Brand } \\
\text { Communication) terhadap variabel mediasi } \\
\text { Me (Brand Trust) }\end{array}$ & 0,778 & $\begin{array}{c}24,676 \\
(>1,96)\end{array}$ & $\begin{array}{c}0,000 \\
(\text { Sig. })\end{array}$ \\
\hline $\mathrm{X}_{2}-\mathrm{Me}$ & $\begin{array}{l}\text { Pengaruh variabel independen (Service } \\
\text { Quality) terhadap variabel mediasi Me (Brand } \\
\text { Trust) }\end{array}$ & 0,812 & $\begin{array}{c}27,788 \\
(>1,96)\end{array}$ & $\begin{array}{l}0,000 \\
(\text { Sig. })\end{array}$ \\
\hline $\mathrm{X}_{3}-\mathrm{Me}$ & $\begin{array}{l}\text { Pengaruh variabel independen (Brand } \\
\text { Personality) terhadap variabel mediasi Me } \\
\text { (Brand Trust) }\end{array}$ & 0,838 & $\begin{array}{c}30,582 \\
(>1,96)\end{array}$ & $\begin{array}{l}0,000 \\
(\text { Sig. }\end{array}$ \\
\hline
\end{tabular}




\begin{tabular}{|c|l|c|c|c|}
\hline $\mathrm{X}_{1}-\mathrm{Y}$ & $\begin{array}{l}\text { Pengaruh variabel independen (Brand } \\
\text { Communication) terhadap variabel dependen } \\
\text { Y(Brand Loyalty) }\end{array}$ & 0,640 & $\begin{array}{c}16,626 \\
(>1,96)\end{array}$ & $\begin{array}{l}0,000 \\
\text { (Sig.) }\end{array}$ \\
\hline $\mathrm{X}_{2}-\mathrm{Y}$ & $\begin{array}{l}\text { Pengaruh variabel independen (Service } \\
\text { Quality) terhadap variabel dependen Y(Brand } \\
\text { Loyalty) }\end{array}$ & 0,610 & $\begin{array}{c}15,369 \\
(>1,96)\end{array}$ & $\begin{array}{l}0,000 \\
\text { (Sig.) }\end{array}$ \\
\hline $\mathrm{X}_{3}-\mathrm{Y}$ & $\begin{array}{l}\text { Pengaruh variabel independen (Brand } \\
\text { Personality) terhadap variabel dependen } \\
\text { Y(Brand Loyalty) }\end{array}$ & 0,650 & $\begin{array}{c}17,079 \\
(>1,96)\end{array}$ & $\begin{array}{l}0,000 \\
\text { (Sig.) }\end{array}$ \\
\hline $\mathrm{Me}-\mathrm{Y}$ & $\begin{array}{l}\text { Pengaruh variabel mediasi Me (Brand Trust) } \\
\text { terhadap variabel dependen } \mathrm{Y}(\text { Brand Loyalty) }\end{array}$ & 0,653 & $\begin{array}{c}17,224 \\
(>1,96)\end{array}$ & $\begin{array}{l}0,000 \\
\text { (Sig.) }\end{array}$ \\
\hline
\end{tabular}

Sumber : Data diolah (ket. T table 0,05two tail 1,96)

Table 3: Ringkasan Hasil Regresi Berganda antara variable Brand Communication,

Service Quality, Brand Personality Brand Trust dan Brand Loyalty

\begin{tabular}{|c|c|c|c|c|c|c|}
\hline \multirow[t]{2}{*}{ Variabel } & \multirow[t]{2}{*}{ Keterangan } & \multicolumn{2}{|c|}{$\begin{array}{l}\text { Besarnya } \\
\text { koefisien }\end{array}$} & \multicolumn{2}{|c|}{ Besarnya t } & \multirow[t]{2}{*}{ Sig. } \\
\hline & & $X$ & $\mathrm{Me}$ & $X$ & $\mathrm{Me}$ & \\
\hline $\mathrm{X}_{1}-\mathrm{Me}-\mathrm{Y}$ & $\begin{array}{l}\text { Pengaruh variabel } \\
\text { independen (Brand } \\
\text { Communication) terhadap } \\
\text { variabel mediasi Me (Brand } \\
\text { Trust) }\end{array}$ & 0,334 & 0,394 & 5.754 & $\begin{array}{c}6,783 \\
(>1,96)\end{array}$ & $\begin{array}{l}0,000 \\
\text { (Sig.) }\end{array}$ \\
\hline $\mathrm{X}_{2}-\mathrm{Me}-\mathrm{Y}$ & $\begin{array}{l}\text { Pengaruh variabel } \\
\text { independen (Service } \\
\text { Quality) terhadap variabel } \\
\text { mediasi Me (Brand Trust) }\end{array}$ & 0,234 & 0,464 & 3.645 & $\begin{array}{c}7,238 \\
(>1,96)\end{array}$ & $\begin{array}{l}0,000 \\
\text { (Sig.) }\end{array}$ \\
\hline $\mathrm{X}_{3}-\mathrm{Me}-\mathrm{Y}$ & $\begin{array}{l}\text { Pengaruh variabel } \\
\text { independen (Brand } \\
\text { Personality) terhadap } \\
\text { variabel mediasi Me (Brand } \\
\text { Trust) }\end{array}$ & 0,345 & 0,364 & 5.124 & $\begin{array}{c}5,412 \\
(>1,96)\end{array}$ & $\begin{array}{l}0,000 \\
\text { (Sig.) }\end{array}$ \\
\hline
\end{tabular}

Sumber : Data diolah (ket. T table 0,05two tail 1,96)

d. Pemeriksaan untuk menguji pengaruh yang ada.

Melihat hasil yang selau signifikan pada analisis SPSS diatas dimana saat regresi antar variable dikontrol dan tanpa kontrol Brand Trust (Me).

\section{PEMBAHASAN}

Melihat hasil-hasil diatas menunjukkan perbandingan pengaruh secara linier antara Brand Communication $\rightarrow$ Brand Trust sebesar $58 \%$, Service Quality $\rightarrow$ Brand Trust sebesar $63,3 \%$ dan Brand Personality $\rightarrow$ Brand Trust sebesar $67,9 \%$ menunjukkan bahwa dari ketiga variable tersebut Brand Personality 
yang memiliki pengaruh paling besar terhadap Brand Trust dibandingkan Brand Communication dan Service Quality.

Variabel Brand Trust merupakan variabel mediasi parsial, yang mampu memediasi hubungan antara Brand communication terhadap Brand Loyalty karena koefisien regresi antara Brand communication terhadap Brand Loyalty masih tetap signifikan tatkala dimasukkan/dikontrol dengan variabel mediasi (Brand Trust). Hasil t hitung menunjukkan lebih besar dari $t$ table $6,52>1,96(\mathrm{n}=400,0,05$, two tail $)$ dan nilai $\mathrm{p}$ sebesar 0,000 lebih kecil dari 0,05. Total pengaruh Brand communication terhadap Brand Loyalty $=0,64$

Variabel Brand Trust merupakan variabel mediasi parsial, yang mampu memediasi hubungan antara Service Quality terhadap Brand Loyalty karena koefisien regresi antara Service Quality terhadap Brand Loyalty masih tetap signifikan tatkala dimasukkan/dikontrol dengan variabel mediasi (Brand Trust). Hasil $t$ hitung menunjukkan lebih besar dari $\mathrm{t}$ table 6,98> $1,96(\mathrm{n}=400 ; 0,05$, two tail) dan nilai $\mathrm{p}$ sebesar 0,000 lebih kecil dari 0,05. Total pengaruh Service Quality terhadap Brand Loyalty $=0,611$.

Brand Trust signifikan mempengaruhi Brand Loyalty setelah di control Brand Personality dengan koefisien 0,364 dan $\mathrm{t}=$ 5,412 dan $\mathrm{X}_{3} \rightarrow \mathrm{Y}$ dikontrol Me dengan hasil menunjukkan Brand Personality signifikan mempengaruhi Brand Loyalty setelah di control Brand Trust dengan koefisien 0,345 dan $\mathrm{t}=5,124$. Sehingga disimpulkan bahwa variabel Brand Trust merupakan variabel mediasi parsial, yang mampu memediasi hubungan antara Brand Personality terhadap Brand Loyalty karena koefisien regresi antara Brand Personality terhadap Brand Loyalty masih tetap signifikan tatkala dimasukkan/dikontrol dengan variabel mediasi (Brand Trust). Hasil t hitung menunjukkan lebih besar dari t table 5,35> $1,96(\mathrm{n}=400 ; 0,05$, two tail $)$ dan nilai $\mathrm{p}$ sebesar 0,000 lebih kecil dari 0,05. Total pengaruh Brand communication terhadap Brand Loyalty $=0,650$

Melihat hasil analisis yang telah dipaparkan di atas mengungkapkan bahwa hipotesis5 (H5) dinyatakan diterima.Jadi, $\mathrm{H}_{0}$ ditolak dan $\mathrm{H} 5$ diterima sehingga Brand Communication, Service Quality dan Brand Personality melalui Brand Trust (mediasi partial) berpengaruh terhadap Brand Loyalty.

Secara teori Compliance gaining dalam komunikasi adalah bentuk persuasi yang pada gilirannya, adalah bentuk pengaruh. Complain gaininng menekankan hasil spesifik: kepatuhan. Penekanannya tidak pada perubahan sikap, tetapi lebih pada behavioural conformity. Penelitian tentang kepatuhan terdiri dari berbagai strategi verbal dan nonverbal untuk meningkatkan kemungkinan mengamankan kepatuhan orang lain(Littlejohn \& Foss, 2009: 155). Strategi verbal dan non verbal merupakan gambaran strategi dari Brand Communication yang berupa iklan (advertising) baik balam bentuk baliho, stiker maupun kalender, direct marketing (dalam bentuk sosialisai/ pertemuan langsung dnegan pemilih), event sepak bola (surround) dan packing (tampilan yang apik dan terencana) disetiap kegiatan yang dilakukan anggota dewan Partai Gerindra yang kemudian memunculkan kepercayaan dan berujung pada pembentukan loyalitas pemilih kepada anggota dewan yang dipilih. Selain itu, service quality yang dilakukan anggota dewan memiliki makna yang kuat di benak pemilih seperti contoh perhatian saat kader/pemilih mengundang pada momen tertentu dan kemudahan dalam menyampaikan gagasan masyarakat kepada 
anggota dewan.Serta penilaian yang baik terhadap indicator-indikator brand personality turut membangun liking pemilih (salahsatu strategi dalam compliance gaining).

Hasil analisis atas service quality anggota dewan yang baik dapat menimbulkan kepercayaan dan ujung-ujungnya adalah loyalitas pemilih. Karena, loyalitas adalah salah satu cara dengan mana konsumen mengungkapkan / nya kepuasan nya dengan kinerja produk atau jasa yang diterima (Bloemer dan Kasper, 1995; Ballester dan Aleman, 2001 dalam Zehir,Sahin, Kitapci dan Osahin, 2011: 1221). Hasil penilaian pemilih yang diwakili dari penilaian respondep pada item-item pernyataan mengukur besaran indicator servis quality yang kemudian setelah dianalisis memiliki pengaruh yang signifikan terhadap brand trust dimana kepercayaan menjadi mediasi antara service quality dan loyalitas.

Brand personality anggota dewan yang tercipta dimata pemilih meningkatkan preferensi konsumen dan penggunaan (Aaker 1997; Sirgy 1982 dalam Sambath \& Fu Jeng, 2005: 435-436), dan meningkatkan tingkat kepercayaan (Aaker 1997; Diamantopoulos et al 2005 dalam Sambath \& Fu Jeng, 2005: 435-436). Dari perspektif manajerial, sebagai anggota dewan selalu mempertimbangkan harapan akan personality yang baik dari dirinya dimata pemilih guna memenangkan kepercayaan pelanggan dalam rangka membangun hubungan. Tentusaja hubungan disini adalah hubungan yang terjalin terus menerus sebagai bentuk loyalitas antara pemilih dengan anggota dewan yang dipilih.

\section{E. PENUTUP}

Penemuan penelitian ini membuktikan bahwa Brand Trust(kepercayaan) sebagai variable mediasi parsialpada variable Brand Communication, Service Quality dan Brand
Personalityyang berpengaruhterhadap brand loyalty (kepatuhan/kesetian) pada pemilih.Brand communication yang mana anggota dewan sebagai markerter harus mampu mengkomunikasikan gagasangagasannya melalui advertising, surround (event), direct marketing dan packing (kemasan/tampilan materi yang disampaikan). Service quality (melalui keluhan dan aspirasi yang diterima anggota dewan) harus mampu mengandung unsur tangible (bukti fisik), rehabilitas (keandalan dalam memberikan pelayanan), responsiveness (kecepatan pelayanan), dan assurance (menanamkan rasa percaya dan keyakinan) kepada pemilih. Brand personality segala sesuatu yang melekat pada pribadi anggota dewan juga menjadi sorotan pemilih bahkan variable ini lebih memiliki pengaruh dibandingkan brand communication dan servis quality.

\section{F. DAFTAR PUSTAKA \\ Buku}

Durianto, Darmadi., Sugiarto, Tony Sitinjak. (2001). Strategi Menaklukkan.Pasar Melalui Riset Ekuitas dan Perilaku Merek. Jakarta: Gramedia. Pustaka Utama Eriyanto. (2007). Teknik Sampling : Analisis Opini Publik. Yogyakarta: LKiS

Ferrinadewi, Erna. (2008) Merek dan Psikologi Konsumen : Implikasi pada Strategi Pemasaran. Yogyakarta: Graha Ilmu

Hermawan, Agus. (2012). Komunikasi

Pemasaran.Jakarta : Penerbit

Erlangga

Kriyantono, Rachmat. (2010). Teknik Praktis Riset Komunikasi.Jakarta : Prenada Media Group. 
Littlejohn \& Foss.(2009). Encyclopedia

of Communication Theory edisi

9.Singapura : SAGE Publication

Littlejohn \& Foss.(2011). Teori

Komunikasi edisi 9. Jakarta:

Salemba Humanika

Lwin, May\& Jim Aitchison. (2002).

Clueless in Marketing

Communication.Jakarta : Penerbit

PT Bhuana Ilmu Populer

McQueen, Josh. (2012). Building Brand

Trust: Discovering the

Advertising Insights Behind Great

Brands. USA: Xlibris Corporation

Newman, Bruce. (1999). Handbook of

Political Marketing. New Delhi:

Sage Publication

Ngatno.(2015). Analisis data variable mediasi dan moderasi dalam riset bisnis dengan program spss.Yogyakarta : CV Farisma Indonesia

Nursal, Adman. (2004). Political Marketing: Strategi Memenagkan Pemilu: Sebuah Pendekatan Baru Kampanye Pemilihan DPR, DPD, Presiden. Jakarta: Gramedia Pustaka Utama

Paraneswara, M.G. (2006). Building

Brand Value: Five Steps to

Building Powerful Brands. India:

Tata McGraw-Hill Education

Philip Kotler, Waldemar Pfoertsch.

(2006). B2B Brand Management.

Heidelberg: Spinger

Rangkuti, Freddy (2002).Creating

Effective Marketing Plan. Jakarta:

Gramedia Pustaka Utama

Reksulak, Michael, Laura Razzolini, William F. Shughart. (2013). The Elgar Companion to Public Choice. USA: Edward Elgar Publishing, Inc
Shimp, Terence A. (2003). Periklanan dan Promosi edisi 5, jilid 1.Jakarta : Erlangga Remaja Rosdakarya

Simamora, Bilson. (2003). Aura Merek : 7 Langkah Membangun Merek Yang Kuat. Jakarta: Gramedia Pustaka Utama

Soehadi, Agus, W. (2005). Effective Branding: Konsep dan Aplikasi Pengembangan Merek yang Sehat dan Kuat. Bandung: Mizan Media Utama

Tjiptono, Fandy and Gregorius Chandra.(2004). Strategi Pemasaran, Edisi 2. Yogyakarta: Penerbit Andi

Yan, Zheng. (2014). Trust Management in Mobile Environments: Autonomic and Usable Models: Autonomic and Usable Models. USA: IGI Global

\section{Jurnal :}

Cemal Zehir, Azize Sahin, Hakan Kitapc1, Mehtap Osahin (2011). "The Effects of Brand Communication and Service Quality In Building Brand Loyalty Through Brand Trust; The Empirical Research On Global Brands," Procedia Social and Behavioral Sciences 24 : p. 1218 1231

Geçti, Fatih and Hayrettin Zengin. (2013). "The Relationship between Brand Trust, Brand Affect, Attitudinal Loyalty and Behavioral Loyalty: A Field Study towards Sports Shoe Consumers in Turkey," International Journal of Marketing Studies; Vol. 5, No. $2:$ p. $111-119$ 
Lau, Geok Theng, and Sook Han Lee. (1999). "Consumers' Trust in a Brand and the Link to Brand Loyalty," Journal of Market Focused Management; Dec 1999; 4, 4 : p. $341-370$

Sambath, Phou, Don Jyh-Fu Jeng (2014). The Effects of Celebrity Endorsers on Brand Personality, Brand Trust, Brand Preference and Purchase Intention, Springer International Publishing: pp 435439

\section{Lain-lain}

BBC Indonesia, (2014 diakses 1 Desember). "Pilpres, pemilu legislatif serentak mulai2019," (http://www.bbc.com)

Komisi Pemilihan Umum, (2014). Perolehan Suara Sah Secara Nasional dalam Pemilihan Umum Anggota Dewan Perwakilan Rakyat (Lampiran keputusan KPU No: 412/Kpts/KPU/TAHUN 2014 tanggal 9 Mei 2014). Jakarta : Komisi Pemilihan Umum

KPU Kabupaten Semarang, (2014). Daftar Pemilih Tetap Pemilihan Umum Anggota DPR, DPD, DPRD Provinsi dan DPRD Kabupaten/Kota Tahun 2014.Ungaran : KPU Kab. Semarang 